\title{
Model of creating an economic ecosystem in the framework of economic convergence under the influence of digitalization
}

\author{
S. Kalayda ${ }^{1^{*}}$ \\ 1 Saint Petersburg State University, St. Petersburg, Russia \\ *s.kalayda@spbu.ru
}

\begin{abstract}
The article contains the study of the capabilities of choosing such a form of joint business organization by an economic convergence initiator which would ensure the maximum growth of such business under the influence of digitalization and thereby the maximum improvement of the initiator's competitive capability. The author has developed a model of creating an economic ecosystem as a really effective ecosystem which takes into account the influence of both positive and possible negative consequences of the impact of digitalization on a joint business and ensures the maximum economic benefits of the joint business. An algorithm has been developed to implement the model in the framework of a certain level and a specific product of digitalization. The main parameters of the model and the algorithm for the implementation of the same are such terms introduced by the author as an economic ecosystem, potentially the most effective economic ecosystem, a real ecosystem, and a really effective ecosystem, which are described by indicators and costs of the economic effect. Following the steps of the algorithm which implements the model will eventually make it possible to create such a version of an economic ecosystem which would bring the highest economic effect to the initiator on a certain convergence level considered when a certain digitalization product is used in the joint business. Comparison of the versions of real ecosystems obtained for each digitalization level and product makes it possible to select the final version which would produce the maximum economic effect for the initiator with respect to convergence levels and digitalization products and hence the maximum growth of the initiator's competitive capacity. The economic ecosystem formed on the basis of the developed model and the algorithm that implements it gives the initiator of the joint business the greatest advantages in a competitive economy.
\end{abstract}

Keywords: digitalization, economic information system, ecosystem, economic convergence, informatization option

For citation: Kalayda S. Model of creating an economic ecosystem in the framework of economic convergence under the influence of digitalization. Prikladnaya informatika=Journal of Applied Informatics, 2021, vol.16, no.6, pp.28-42. DOI: 10.37791/2687-0649-2021-16-6-28-42 


\title{
Модель формирования экономической экосистемы в рамках экономической конвергенции под влиянием цифровизации
}

\author{
C. A. Калайда ${ }^{*}$ \\ ${ }^{1}$ Санкт-Петербургский государственный университет, Санкт-Петербург, Россия \\ *s.kalayda@spbu.ru
}

\begin{abstract}
Аннотация. Развитие рыночных отношений под воздействием новых тенденций общественного развития приводит к необходимости трансформации экономики, в том числе к поиску новых эффективных форм организации совместного бизнеса. В статье исследуются возможности выбора инициатором совместной деятельности такой формы организации бизнеса, реализуемого в рамках определенного уровня экономической конвергенции, которая под воздействием цифровизации обеспечивает его наибольший рост и, как следствие, максимальное повышение конкурентоспособности инициатора. Автор разработал модель формирования экономической экосистемы как реально эффективной, учитывающей влияние на совместный бизнес как положительных, так и возможных отрицательных последствий цифровизации, которая обеспечивает максимальный экономический эффект совместного бизнеса. Для реализации этой модели в рамках определенного уровня конвергенции и применения в совместном бизнесе конкретного продукта цифровизации разработан алгоритм. Основными параметрами модели и реализующего ее алгоритма являются такие введенные автором понятия, как «экономическая экосистема», «потенциально самая эффективная экономическая экосистема», «реальная экосистема», «реально эффективная экосистема», описываемые показателями экономического эффекта и затрат по его получению. Следование шагам алгоритма, реализующего модель, позволит сформировать такой вариант экономической экосистемы, который обеспечит инициатору на определенном рассматриваемом уровне конвергенции при использовании в совместном бизнесе конкретного продукта цифровизации самый большой экономический эффект. Сравнение полученных по каждому уровню и продукту цифровизации вариантов реально эффективных экосистем дает возможность отбора окончательного варианта экосистемы, обеспечивающего инициатору экономический эффект, максимальный по уровням конвергенции и продуктам цифровизации, и, как следствие, наибольший рост его конкурентоспособности. Сформированная на основе разработанной модели и реализующего ее алгоритма экономическая экосистема дает в условиях конкурентной экономики инициатору создания совместного бизнеса наибольшие преимущества.
\end{abstract}

Ключевые слова: цифровизация, экономическая информационная система, экосистема, экономическая конвергенция, вариант информатизации

Для цитирования: Калайда С. A. Model of creating an economic ecosystem in the framework of economic convergence under the influence of digitalization // Прикладная информатика. 2021. T. 16. № 6. С. 28-42. DOI: 10.37791/2687-0649-2021-16-6-28-42

\section{Introduction}

T he term "ecosystem" was first used in 1935 by British ecologist Arthur Tansley with regard to nature [1]. An ecosystem was and still is understood as the interrelation of all elements of nature: living beings, natural forces, etc., but such interrelation that manifests not only in the common coexistence but also in the competition of the natural elements. This is why 